\title{
A Novel Bispecific Antibody Targeting CD3 and Lewis Y with Potent Therapeutic Efficacy against Gastric Cancer
}

\author{
Jie Chen ${ }^{1}$, Zhidi Pan ${ }^{1}$, Lei Han ${ }^{2,3}$, Yuexian Zhou ${ }^{1}$, Huifang Zong ${ }^{1}{ }^{(D)}$, Lei Wang ${ }^{1}$, Rui Sun ${ }^{1}$, Hua Jiang ${ }^{2,4}$, \\ Yueqing Xie ${ }^{4}$, Yunsheng Yuan ${ }^{1}$, Mingyuan $\mathrm{Wu}^{1}{ }^{1}$, Yanling Bian ${ }^{1}$, Baohong Zhang ${ }^{1, * \mathbb{C}}$ and Jianwei Zhu ${ }^{1, *}$ \\ 1 Engineering Research Center of Cell and Therapeutic Antibody, Ministry of Education, School of Pharmacy, \\ Shanghai Jiao Tong University, Shanghai 200240, China; jacy0214@sjtu.edu.cn (J.C.); \\ panzhidi@sjtu.edu.cn (Z.P.); yuexianzhou@sjtu.edu.cn (Y.Z.); zhaoxiliunian@sjtu.edu.cn (H.Z.); \\ lwangph@sjtu.edu.cn (L.W.); sun-rui@sjtu.edu.cn (R.S.); yunsheng@sjtu.edu.cn (Y.Y.); \\ wumingyuan@sjtu.edu.cn (M.W.); weixiaobyl@sjtu.edu.cn (Y.B.) \\ 2 Jecho Biopharmaceuticals Co., Ltd., Tianjin 300450, China; lei_han@alumni.sjtu.edu.cn (L.H.); \\ hjiang@jechoinc.com (H.J.) \\ 3 Jecho Biopharmaceutical Institute, Shanghai 200240, China \\ 4 Jecho Laboratories, Inc., Frederick, MD 21704, USA; yxie@jechoinc.com \\ * Correspondence: bhzhang@sjtu.edu.cn (B.Z.); jianweiz@sjtu.edu.cn (J.Z.)
}

check for updates

Citation: Chen, J.; Pan, Z.; Han, L.; Zhou, Y.; Zong, H.; Wang, L.; Sun, R.; Jiang, H.; Xie, Y.; Yuan, Y.; et al. A Novel Bispecific Antibody Targeting CD3 and Lewis $Y$ with Potent Therapeutic Efficacy against Gastric Cancer. Biomedicines 2021, 9, 1059. https://doi.org/10.3390/

biomedicines 9081059

Academic Editor: Paola Maroni

Received: 3 June 2021

Accepted: 18 August 2021

Published: 20 August 2021

Publisher's Note: MDPI stays neutral with regard to jurisdictional claims in published maps and institutional affiliations.

Copyright: (c) 2021 by the authors. Licensee MDPI, Basel, Switzerland. This article is an open access article distributed under the terms and conditions of the Creative Commons Attribution (CC BY) license (https:// creativecommons.org/licenses/by/ $4.0 /)$.

\begin{abstract}
Lewis $\mathrm{Y}$ antigen, a glycan highly expressed on most epithelial cancers, was targeted for cancer treatment but lacked satisfactory results in some intractable and refractory cancers. Thus, it is highly desirable to develop an effective therapy against these cancers, hopefully based on this target. In this work, we constructed a novel T cell-engaging bispecific antibody targeting Lewis $\mathrm{Y}$ and CD3 (m3s193 BsAb) with the IgG-[L]-scfv format. In vitro activity of m3s193 BsAb was evaluated by affinity assay to target cells, cytotoxicity assay, cytokines releasing assay, and T cells proliferation and recruiting assays. Anti-tumor activity against gastric cancer was evaluated in vivo by subcutaneous huPBMCs/tumor cells co-grafting model and huPBMCs intravenous injecting model. In vitro, m3s193 BsAb appeared to have a high binding affinity to Lewis $\mathrm{Y}$ positive cells and Jurkat cells. The BsAb showed stronger activity than its parent mAb in $\mathrm{T}$ cell recruiting, activation, proliferation, cytokine release, and cytotoxicity. In vivo, m3s193 BsAb not only demonstrated higher therapeutic efficacy in the huPBMCs/tumor co-grafting gastric carcinoma model than the parent $\mathrm{mAb}$ but also eliminated tumors in the model of intravenous injection with huPBMCs. Strong anti-tumor activity of m3s193 BsAb revealed that Lewis Y could be targeted in T cell-engaging BsAb for gastric cancer therapy.
\end{abstract}

Keywords: Lewis Y; T cell-engaging bispecific antibody; m3s193 BsAb; cancer therapy

\section{Introduction}

Bispecific antibody (BsAb) has achieved a great accomplishment in fighting against diseases, including cancers. To date, three BsAbs have been on the market, and many others are in clinical research for different diseases [1]. Among them, T cell-engaging BsAbs were focused on the therapy for various cancers due to their potent activity by activating the immune system [2-4]. Typically, a BsAb has two arms that may target tumor association antigens on tumor cells and CD3 on T cells, which could recruit T cells into the tumor micro-environment as well as activate $\mathrm{T}$ cells to release cytokines, granzyme, and perforin [4].

Many cancer cell surface antigens, such as CD19, Her2, and GD2, were targeted through T cell-engaging BsAbs, showing potent anti-tumor activity [5-7]. Lewis $\mathrm{Y}$, as a tumor-associated glycan antigen, is a type 2 blood group-related difucosylated oligosaccharide with the chemical structure $[\mathrm{Fuc} \alpha 1 \rightarrow 2 \mathrm{Gal} \beta 1 \rightarrow 4(\mathrm{Fuc} \alpha 1 \rightarrow 3) \mathrm{GlcNAc} \beta 1 \rightarrow \mathrm{R}]$, and fucosylated by $\alpha 1,2$-fucosyltransferase at the end of glycan chain [8,9]. It was also targeted 
for anti-tumor treatment $[10,11]$. The primary expression of Lewis $Y$ was in the embryonic period, and there was limited expression on the surface of granulocytes and epithelium in adults under the physiological condition [12]. Many studies also found that Lewis $Y$ was in a form of glycolipid on the plasma membrane or conjugated to other cell receptors, such as EGFR, CD47, CD44, and CD147 [13-16]. Nevertheless, Lewis Y was highly expressed in the majority of carcinomas, including breast, ovary, colon, stomach, and liver cancers $[17,18]$. Additionally, its expression was often related to clinical stage and progression $[19,20]$. Several studies revealed that expression of Lewis $Y$ on ovarian cancers could promote cancer cell proliferation by regulating expression and phosphorylation of the molecules in EGFR/PI3K/Akt signaling pathways [21,22] and as a part of integrin $\alpha \mathrm{V}, \beta 3$, and $\alpha 5 \beta 1$ to enhance the adhesion and migration of ovarian cancer cells [23-25]. Besides ovarian cancer, $44 \%$ of cases of breast carcinomas were Lewis Y positive, and over-expression of Lewis $Y$ was associated with a significantly decreased patient survival rate [19]. A clinical study on gastric cancer also revealed that $40-50 \%$ of cases were Lewis $\mathrm{Y}$ reactive and a significant strong expression on signet-ring cell carcinomas of the stomach [26].

Antibody targeting Lewis Y not only inhibited tumor growth but also enhanced anti-tumor activity when combined with taxol chemotherapy in breast cancer xenograft studies [11,27]. Anti-Lewis $Y$ antibody also enhanced the therapeutic efficacy of celecoxib against gastric cancer by downregulation of MAPKs/COX-2 signaling pathway [28]. Researchers found that knockdown of FUT1 (gene of $\alpha 1$,2-fucosyltransferase), a key enzyme for Lewis $Y$ synthesis, could down-regulate HER2 signaling via EGFR down-regulation to inhibit the proliferation of the gastric cancer cell line (NCI-N87) [29]. All these studies suggested that Lewis $Y$ was a promising target for the therapy of epithelial cancers including ovarian, breast, and gastric cancers. Lewis $Y$ has been evaluated as a target in several clinical trials using monoclonal antibody $(\mathrm{mAb})$, antibody-drug conjugate (ADC), and chimeric antigen receptor T-Cell immunotherapy (CAR-T); however, a limited clinical benefit has been achieved so far from these trials [30,31].

$\mathrm{T}$ cell-engaging BsAbs have many advantages with different formats produced by various platforms [1,32]. Among them, IgG-[L]-scfv-like T cell-engaging BsAbs had potent anti-tumor activity to different tumor cell lines by targeting tumor association antigens and CD3 $[6,33,34]$, which was confirmed by another anti-tumor BsAb in our laboratory (data not shown). Brian H. Santich et al. also reported that the IgG-[L]-scfv structure had stronger anti-tumor activity than either the IgG-like or BiTE structure for the GD2 target with appropriate inter-domain spacing and spatial configuration [7]. Thus, we were inspired by the successful reports and designed m3s193 BsAb with an IgG-[L]-scfv structure to evaluate in vitro and in vivo anti-tumor activity. Here, we report that this BsAb had an excellent curative effect against Lewis $Y$ positive gastric cancer, showing the potential to be a new therapeutic regent in clinical applications.

\section{Materials and Methods}

\subsection{Vectors Construction}

The variable heavy chain (VH) sequences and variable light chain (VL) sequences of anti-Lewis $\mathrm{Y}$ antibody and Lewis $\mathrm{Y}$-BsAb were derived from murine monoclonal antibody $3 S 193$ (United States Patent 5874060) [9] and synthesized by GenScript ${ }^{\circledR}$ company (Nanjing, China). VH and VL were constructed into the human IgG1, $\mathrm{k}$ framework by PCR technology to obtain monoclonal antibody anti-Lewis $\mathrm{Y}$, named m3s193 mAb. Furthermore, Lewis $\mathrm{Y}$-BsAb was constructed by $\mathrm{VH}$ and $\mathrm{VL}$ of m3s193 into the human IgG1, $\mathrm{k}$ framework with mutations of L234A, L235A, and P329G (LALA-PG) to eliminate Fc receptor and complement binding activities [35]. Anti-CD3 scfv derived from the VH and VL domains of huOKT3 [36] was fused to the C-terminal of each light chain by a linker of three $\mathrm{G}_{4} \mathrm{~S}_{1}$ domains to form $\mathrm{T}$ cell-engaging $\mathrm{BsAb}$, named m3s193 BsAb. An additional six $\mathrm{G}_{4} \mathrm{~S}_{1}$ domains were added as a linker between the VH and VL domains of the scfv. For the negative control with similar IgG-[L]-scfv BsAb format, $\mathrm{VH}$ and $\mathrm{VL}$ of anti-CD22 sequence derived from M971 (United States Patent 9598492) [37] were synthesized and constructed 
by the same method, named M971 BsAb. All coding sequences of heavy/light chains were constructed into pcDNA3.4 vector by homologous recombination.

\subsection{Proteins Purification}

The constructed vectors were transfected into HEK293F cells using transient gene expression (TGE) technology following published protocols [38-40]. After 6-7 days' culture, when the cell viability dropped to $50-60 \%$, the supernatant was harvested and purified by MabSelect SuRe affinity chromatography. Purified $\mathrm{mAb}$ and BsAbs were detected by SDS-PAGE to verify the molecule weight under non-reducing and reducing conditions. All purified proteins were dialyzed overnight in phosphate-buffered saline (PBS) buffer and sterilized by filtration using a $0.22 \mu \mathrm{m}$ filter and frozen in $-80^{\circ} \mathrm{C}$ freezer.

\subsection{Binding Activity to the Target Cells}

Four Lewis $\mathrm{Y}$ positive tumor cell lines were selected for the binding activity assay by flow cytometry. In brief, 0.2 million MCF-7, T47D, MDA-MA-231, and NCI-N87 cells were incubated with $5 \mu \mathrm{g}$ of purified $\mathrm{mAb}$ and $\mathrm{BsAb}$, respectively, in $4{ }^{\circ} \mathrm{C}$ for $30 \mathrm{~min}$. After incubation, cells were washed twice with FACS buffer (2\% FBS in PBS) and then incubated with FITC-conjugated goat anti-human IgG $(\mathrm{H}+\mathrm{L})$ secondary antibody (TheromFisherTM, Shanghai, China, Cat no. A18806) in $4{ }^{\circ} \mathrm{C}$ for $30 \mathrm{~min}$. Finally, cells were washed twice with FACS buffer and analyzed with CytoFLEX cytometry (Beckman Coulter, Inc, Brea, CA, USA model number: CytoFLEX). Binding histograms were exported by CytExpert software (Beckman Coulter, Inc., Version: 2.3.0.84).

\subsection{Binding Affinity to the Target Cells}

In this assay, target cells were harvested and washed twice with FACS buffer and were equalized into round 96-well cell culture plates with 2E5 cells/well. Antibody m3s193 mAb or m3s193 BsAb was diluted 5 times, then incubated with target cells in $4{ }^{\circ} \mathrm{C}$ for $30 \mathrm{~min}$ under a final concentration from $500 \mathrm{nM}$ to $0.0064 \mathrm{nM}$. For Jurkat cells, instead of T cells due to CD3 expression on its surface, 0.2 million cells were incubated with m3s193 BsAb diluted from $500 \mathrm{nM}$ to $0.032 \mathrm{nM}$ in $4{ }^{\circ} \mathrm{C}$ for $30 \mathrm{~min}$. After incubation, all cells were washed and incubated with secondary antibody FITC as previously described and then detected by CytoFLEX cytometry. Finally, median fluorescence intensity was counted for each sample and analyzed by GraphPad Prism.

\subsection{In Vitro Cytotoxicity Mediated by huPBMCs}

Target cells were seeded on 96-well cell culture plates with culture medium (no phenol RPMI 1640 (Gibco, Cat no. 11835030) + 5\% FBS (Gibco, Shanghai, China, Cat no. 10100147)) overnight. Purified antibodies were added with various concentrations (10-fold dilution) diluted by the culture medium (no phenol RPMI $1640+2 \%$ FBS). Fresh isolated huPBMCs were added with a 10:1 E/T ratio. After incubation, the supernatant was collected, and the lactate dehydrogenase activity was measured using Cytotoxic $96^{\circledR}$ Non-Radioactive Cytotoxicity Assay Kit (Promega, Madison, WI, USA Cat no. G1780). All measurements were in triplicate. The percentage of cytotoxicity was calculated as follows: cytotoxicity $\%=$ (experimental lysis - spontaneous effector lysis - spontaneous target lysis)/(maximum target lysis - spontaneous target lysis) $\times 100$, and data were analyzed by GraphPad Prism.

\section{6. $T$ Cells Activation with CD69 and CD25 Expression}

Lewis Y positive NCI-N87 cells were seeded on 96-well cell culture plates (2E4 cells/well) overnight. On the second day, cells were incubated with fresh isolated huPBMCs $(\mathrm{E}: \mathrm{T}=10: 1)$ under various concentrations of diluted antibodies and then incubated for $20 \mathrm{~h}$ or $90 \mathrm{~h}$ at $37^{\circ} \mathrm{C}$. After $20 \mathrm{~h}$ incubation, the cell mixture (target cells and huPBMCs) was collected and plated on round 96-well cell culture plates and then analyzed by flow cytometry using CD8-FITC, CD4-PE (Sino Biological, Beijing, China), and CD69-APC mAbs (BD Biosciences, San Jose, CA, USA) to detect the expression of CD69 on CD8 ${ }^{+}$and CD4 ${ }^{+} \mathrm{T}$ 
cells. In another similar assay, after $90 \mathrm{~h}$ incubation, the cell mixture was analyzed with the same method using CD8-FITC, CD4-PE, and CD25-APC mAbs (Sino Biological) to detect the expression of $\mathrm{CD} 25$ on $\mathrm{CD}^{+}$and $\mathrm{CD}^{+}{ }^{+} \mathrm{T}$ cells. Finally, $\mathrm{CD} 69^{+}$and $\mathrm{CD} 25^{+}$percentage and median fluorescence intensity on $\mathrm{CD}^{+}$and $\mathrm{CD}^{+} \mathrm{T}$ cells were counted for each sample and analyzed by GraphPad Prism.

\subsection{Detection of Cytokine Release}

NCI-N87 cells were seeded on 96-well cell culture plates (2E4 cells/well) overnight. On the second day, cells were incubated with fresh isolated huPBMCs $(\mathrm{E} / \mathrm{T}=10: 1)$ and treated with various concentrations of diluted antibodies at $37^{\circ} \mathrm{C}$. After 20 or $25 \mathrm{~h}$ of incubation, cells were centrifugalized with $1500 \mathrm{rpm}(10 \mathrm{~min})$, and the supernatant was harvested and frozen in $-80^{\circ} \mathrm{C}$ freezer immediately. Cytokine detection was performed by ELISA assay kit (R\&D SYSTEM ${ }^{\circledR}$, Minneapolis, MN, USA) following manual instruction. In brief, detection antibodies of IL-2 and IFN- $\gamma$ were coated on ELISA high-adsorption plate with working concentration overnight. After incubation, plates were washed and blocked for $1 \mathrm{~h}$. Next, IL-2, IFN- $\gamma$, and thawed supernatant were diluted, respectively, with appropriate concentrations followed by incubation for $2 \mathrm{~h}$. Finally, detection antibodies of IL-2 and IFN- $\gamma$ were added with working concentration for $2 h$, followed by adding streptavidin-HRP, substrate solution, and stop solution as instructed by manual. The OD at $450 \mathrm{~nm}$ was measured with micro-plate reader (Infinite M200 Pro, Tecan, Shanghai, China), and data were analyzed by GraphPad Prism.

\subsection{T Cell Proliferation Assay}

HuPBMCs were labeled with CellTrace CFSE dye at a final concentration of $1 \mu \mathrm{M}$, and then CFSE-labeled huPBMCs were co-cultured with NCI-N87 cells with a 10:1 E/T ratio. This mixture was then treated with $100 \mathrm{ng} / \mathrm{mL} \mathrm{m} 3 \mathrm{~s} 193 \mathrm{mAb}$ or $\mathrm{BsAb}$ at $37{ }^{\circ} \mathrm{C}$. After incubation, the mixture was harvested daily from day 1 to day 4 with labeling of mouse anti-human CD3 APC-labeled (Sino Biological) mAbs and then analyzed by flow cytometry. Percentage of $\mathrm{T}$ cell proliferation was calculated by quantitation of the low CFSE fluorescence intensity contributed by proliferated $\mathrm{CD}^{+} \mathrm{T}$ cells.

\subsection{Cell-Cell Association Mediated by m3s193 BsAb}

Lewis Y positive NCI-N87 cells were labeled with CellTrace CFSE (Invitrogen, Shanghai, China) at a final concentration of $0.5 \mu \mathrm{M}$. The CD3-expressing Jurkat cells were labeled by PKH26 dye using a cell membrane labeling kit (Sigma; PKH26GL) according to the manufacturer's protocols. Labeled cells $\left(1 \times 10^{6} / \mathrm{mL}\right)$ were mixed at equal ratio in the presence or absence of $\mathrm{mAb}$ or $\mathrm{BsAb}(10,100$ and $1000 \mathrm{ng} / \mathrm{mL})$ in a $4{ }^{\circ} \mathrm{C}$ incubator for $30 \mathrm{~min}$ referring to previous report [32]. Population of cell-cell association was measured using flow cytometry and was quantified as the percentage of double-positive cells in the upper right quadrant of FITC-A compared with PE-A, representing the CFSE+PKH26+ cell assembly.

\subsection{In Vivo Activity of m3s193 BsAb with huPBMCs/Tumor Cells Co-Grafting Model}

Female NOD/SCID mice (6-8 weeks, Charles River Labs) were purchased and fed in accordance with guidelines from the Institutional Animal Care and Use Committee of the School of Pharmacy of Shanghai Jiao Tong University (SJTU). NCI-N87 cells (5E6 cells) were admixed with freshly isolated huPBMCs at the indicated E/T ratios of 1:3. HuPBMCs/tumor cell mixture was co-grafted (injected) s.c. (subcutaneously) in NOD/SCID mice in a total volume of $0.1 \mathrm{~mL}$ in RPMI medium. After co-grafting, therapy administration i.v. (intravenously) $(200 \mu \mathrm{L})$ was performed either day 0 at the indicated doses and schedules twice a week or was continuously dosed from day 0 to day 6 every day. Tumor size was measured twice a week with a vernier caliper, and tumor volume was calculated using the approximated formula $\mathrm{V}=0.5 \times($ length $\times$ width $\times$ width). Mice were euthanized when the tumor size reached $1000 \mathrm{~mm}^{3}$. After the mice were sacrificed, 
the tumor weight was detected by the electronic analytical balance and stripped tumors were photographed.

\subsection{In Vivo Activity of m3s193 BsAb with huPBMCs Intravenous Injection Model}

Female NOG mice (6-8 weeks, Charles River Labs) were injected s.c. with NCI-N87 cells (5E6 cells) and tumor volume was measured every 3 days. Mice were randomized into two groups for PBS and m3s193 BsAb $(n=8)$ when the tumor volume achieved $100 \mathrm{~mm}^{3}$ and injected with huPBMCs i.v. (5E6 cells). Therapy administration started 3 days after huPBMCs transfer, with i.v. injection of $100 \mu \mathrm{g}$ m3s193 BsAb or $200 \mu \mathrm{L}$ PBS (vehicle) every 3 days. Mice were sacrificed when GVHD happened. For huPBMCs reconstruction assay, single-cell suspension derived from mice peripheral blood after huPBMCs injected for 14 days was stained with anti-huCD45 antibody (Sino Biological), and percentage of human CD $45^{+}$cells was calculated and analyzed by GraphPad Prism.

\subsection{Histologic Analysis}

Tumor tissues from termination animals were fixed in 4\% PFA (paraformaldehyde) overnight and embedded in paraffin. Briefly, $4 \mu \mathrm{m}$ sections were cut using a microtome (Leica) and mounted on glass slides. Samples were deparaffinized, and heat antigen retrieval was performed before immune-staining for human CD3, CD4, and CD8 using corresponding mAbs (Servicebio). The sections were counterstained with hematoxylin (Servicebio), and slides were scanned using OLYMPUS-BX53.

\section{Results}

\subsection{Expression and Purification of the Antibodies}

Bispecific antibody (m3s193 BsAb) was designed and constructed as an IgG-[L]-scfv structure, and two constructs for experimental controls were m3s193 mAb and M971 BsAb (Table 1). All three antibodies were expressed in HEK293F cells and purified by MabSelect SuRe affinity chromatography. IgG-[L]-scfv BsAb had a symmetrical structure with a normal heavy chain and a light chain with a C-terminal linker $\left(G_{4} S_{1}\right)_{3}$ followed by huOKT3 scfv (Figure 1a). After expression in HEK293F cells, all proteins were purified and analyzed by SDS-PAGE to verify both quality and quantity. Two banes appeared in the antibody m3s193 mAb under the reducing condition, representing the heavy chain (about $50 \mathrm{kDa}$ ) and light chain (about $25 \mathrm{kDa}$ ) (Figure 1b). The m3s193 BsAb showed one bane at about $200 \mathrm{kDa}$ under the non-reducing condition and one bane at about $50 \mathrm{kDa}$ under the reducing condition (Figure 1c), which was consistent with the theoretical molecular weight of heavy and light chains of m3s193 BsAb. For the negative control M971 BsAb, two separate banes under the reducing condition were observed by SDS-PAGE analysis (Figure 1d), due to size differences of heavy and light chains. From these results, it was concluded that all three proteins were well expressed in mammalian cell line HEK293F with reasonable yield. After one-step purification, product purity could reach above 95\% for $\mathrm{BsAb}$ that met the requirement for in vitro and in vivo assays (Table 1, Figure S1).

Table 1. Antibodies used in this study.

\begin{tabular}{ccccc}
\hline Name & Structure & Fc Mutation & Target & SEC-HPLC Purity (\%) \\
\hline m3s193 mAb & IgG1 & No & Lewis Y & $92.63 \%$ \\
m3s193 BsAb & IgG-[L]-scfv & LALA-PG & Lewis Y and CD3 & $98.44 \%$ \\
M971 BsAb & IgG-[L]-scfv & LALA-PG & CD22 and CD3 & $98.79 \%$ \\
\hline
\end{tabular}


a

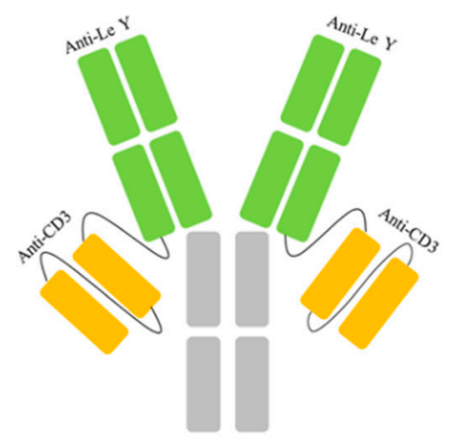

b

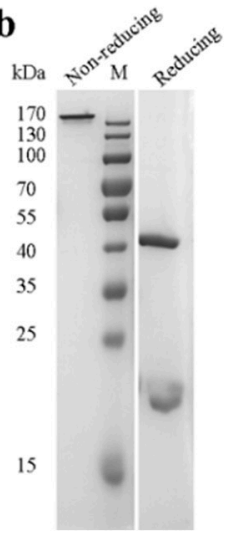

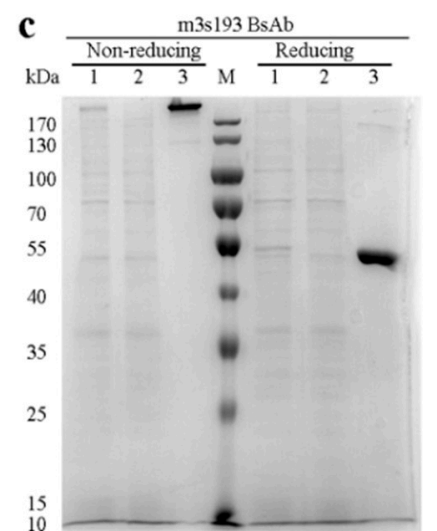

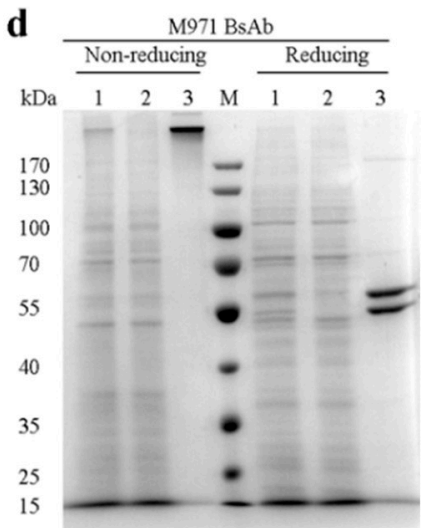

Figure 1. Structure schematic of m3s193 BsAb and purification of the proteins. (a) Molecular design of m3s193 BsAb with IgG-[L]-scfv structure. (b) SDS-PAGE analysis of purified m3s193 mAb. (c) SDS-PAGE analysis of purified m3s193 BsAb. (d) SDS-PAGE analysis of purified M971 BsAb. Lane 1, the supernatant before purification; lane 2, the flow through after purification; and lane 3 , the elution of proteins.

\subsection{Binding Activity of Purified Proteins}

Previous studies revealed that Lewis $Y$ was expressed on breast and gastric cancers $[19,26]$. Three breast cancer cell lines (MCF-7, T47D, MDA-MB-231) and one gastric cancer cell line (NCI-N87) were used to detect the expression of Lewis $\mathrm{Y}$ and to analyze the binding activity of purified antibodies. We found that all cancer cell lines selected expressed Lewis $\mathrm{Y}$ and had bound m3s193 mAb and m3s193 BsAb in the flow cytometry assay (Figure 2a). On the MDA-MB-231 cell line, m3s193 BsAb had a slightly higher fluorescence intensity than the m3s193 mAb. For the negative control M971 BsAb, no binding to the NCI-N87 cell line was observed (Figure 2a). Next, we detected the binding affinity of m3s193 mAb and $\mathrm{m} 3 \mathrm{~s} 193 \mathrm{BsAb}$ to the target tumor cells and found that both antibodies had a similar binding affinity curve to Lewis $\mathrm{Y}$ positive tumor cell lines, suggesting that BsAb maintained the high affinity of parent $\mathrm{mAb}$ (Figure $2 \mathrm{~b}$ ). The result of binding to the Jurkat cell line also revealed that m3s193 $\mathrm{BsAb}$ had a high binding affinity to Jurkat cells with a low $\mathrm{EC}_{50}$ value $(1.035 \mathrm{nM})$ (Figure $2 \mathrm{~b}$ ), indicating that the bivalent binding model of the IgG-[L]-scfv structure possibly maintained the high affinity of BsAb to target cells.

$\mathbf{a}$
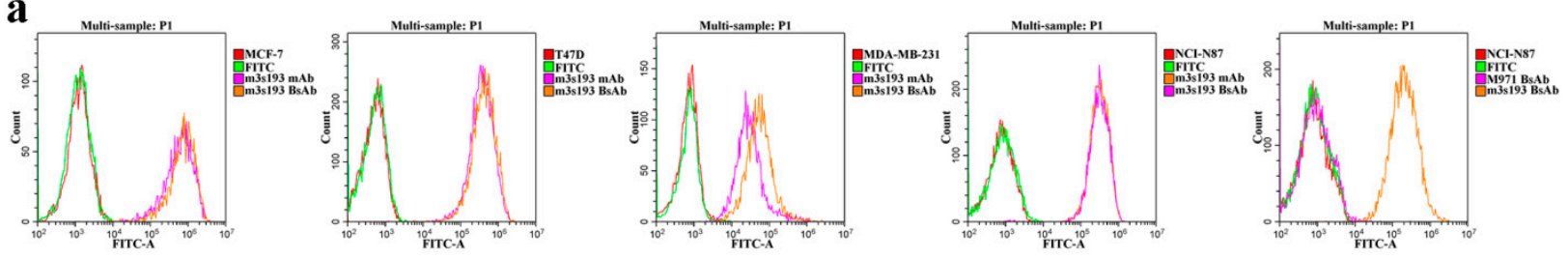

b
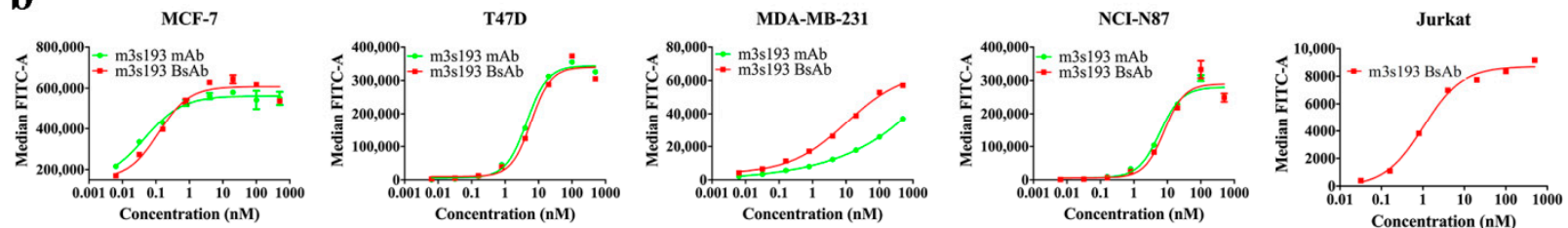

Figure 2. Cont. 

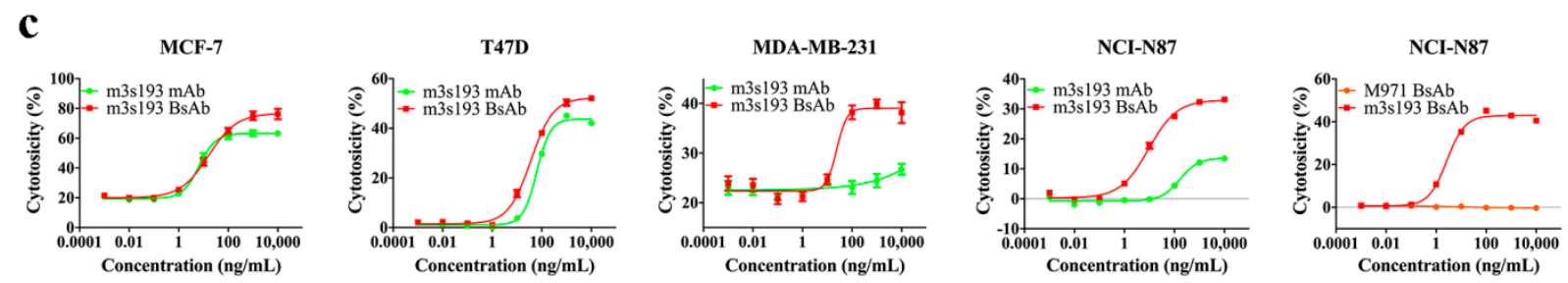

Figure 2. Flow cytometry binding analysis and in vitro cytotoxicity mediated by huPBMCs. (a) FACS histograms of Lewis $Y$ expression in different cancer cell lines and binding of m3s193 mAb, m3s193 BsAb, and M971 BsAb to the cells. (b) Binding affinity curve of m3s193 mAb and m3s193 BsAb to four target tumor cell lines and Jurkat cell line. Median fluorescence intensity (MFI) of each sample indicated the binding potency was analyzed by GraphPad Prism. (c) Cytotoxicity to four target tumor cells mediated by huPBMCs in the presence of proteins. Data are shown as means \pm SD with three replicates.

\section{3. $T$ Cell Cytotoxicity Mediated by m3s193 BsAbs}

We designed the bispecific antibody as an IgG-[L]-scfv structure and observed potent T cell redirecting cytotoxicity to target tumor cells, as previously reported [7]. To MCF-7 and T47D cells, potent cytotoxicity was observed with m3s193 mAb, potentially due to their sensitivity to ADCC activity by m3s193 mAb. M3s193 BsAb achieved similar cytotoxicity as $\mathrm{m} 3 \mathrm{~s} 193 \mathrm{mAb}$ with a comparable $\mathrm{EC}_{50}$ value and a slightly higher potency (Table 2, Figure 2c). To MDA-MB-231 and NCI-N87 cells, in contrast, m3s193 BsAb had much better T cell-mediated cytotoxicity than $\mathrm{m} 3 \mathrm{~s} 193 \mathrm{mAb}$, with a lower cytotoxicity $\mathrm{EC}_{50}$ value and a remarkably higher cytotoxicity in cell killing percentage. These results demonstrated that m3s193 BsAb had better in vitro activity than m3s193 mAb. In an independent cytotoxicity comparison study between the two BsAbs, no cytotoxicity was observed with M971 BsAb except basal noise, while m3s193 BsAb reproducibly exhibited low cell killing $\mathrm{EC}_{50}$ at $2.673 \mathrm{ng} / \mathrm{mL}$. This suggested that T cell-mediated tumor cell killing by the IgG-[L]-scfv was dependent on the target expression on tumor cells. M3s193 BsAb would be expected to have less non-specific toxicity and minimum cytotoxicity to Lewis $Y$ negative expression tissues in the body. The slight $\mathrm{EC}_{50}$ differences $(9.315$ and $2.673 \mathrm{ng} / \mathrm{mL})$ in two experiments observed in NCI-N87 cytotoxicity mediated by m3s193 BsAb might be due to the differences of huPBMCs donors.

Table 2. Cytotoxicity $\mathrm{EC}_{50}(\mathrm{ng} / \mathrm{mL})$ mediated by the antibodies.

\begin{tabular}{cccccc}
\hline Cells & MCF-7 & T47D & MDA-MB-231 & NCI-N87 & \multirow{2}{*}{ NCI-N87 } \\
\hline Proteins & & & & & \\
m3s193 mAb & 6.689 & 62.52 & $2.296 \mathrm{E}+15$ & 162.5 & \\
m3s193 BsAb & 162.5 & 35.89 & 23.98 & 9.315 & 2.673 \\
M971 BsAb & & & & & ND $^{*}$ \\
\hline
\end{tabular}

ND*: No cytotoxicity was observed.

\section{4. $T$ Cell Activation Mediated by m3s193 BsAb}

T cell-engaging BsAbs could activate T cells with the expression of CD69 and CD25 as previously reported [41]. By flow cytometry assay, CD69 expression on T cells was activated by $\mathrm{m} 3 \mathrm{~s} 193 \mathrm{BsAb}$ but not by $\mathrm{m} 3 \mathrm{~s} 193 \mathrm{mAb}$. The percentage of $\mathrm{CD} 8^{+} \mathrm{CD} 69^{+}$in $\mathrm{CD} 8^{+}$ and $\mathrm{CD} 4^{+} \mathrm{CD}_{6} 9^{+}$in $\mathrm{CD} 4^{+}$achieved nearly $100 \%$ (Figure 3a). MFI data further proved the potent activation of $\mathrm{T}$ cells by $\mathrm{m} 3 \mathrm{~s} 193 \mathrm{BsAb}$ with high CD69 expression at the concentration from 100 to $10,000 \mathrm{ng} / \mathrm{mL}$, while no CD69 expression on $\mathrm{CD}^{+}$and $\mathrm{CD} 4^{+} \mathrm{T}$ cells was detected for the control $\mathrm{mAb}$ even at a high concentration. This observation was further confirmed by the negative control M971 BsAb (Figure 3b). This suggested that m3s193 BsAb but not m3s193 mAb could activate T cells, and the activation was dependent on antigen expression on the tumor cells. By the detection of CD25, a later activation marker on $\mathrm{T}$ cells, we found that a similar result was observed as CD69 expression on CD8 ${ }^{+}$and $\mathrm{CD} 4^{+} \mathrm{T}$ cells mediated by m3s193 BsAb and M971 BsAb (Figure 3c), demonstrating the continuous activation of $\mathrm{CD}^{+}$and $\mathrm{CD} 4^{+} \mathrm{T}$ cells by $\mathrm{m} 3 \mathrm{~s} 193 \mathrm{BsAb}$ from the early to later phase but not 
the control mAb and M971 BsAb. To eliminate the impact from huPBMCs' auto-activation, a quantity of $\mathrm{CD} 69$ positive T cells in $\mathrm{CD}^{+}$and $\mathrm{CD} 4^{+}$cells was detected with the mixture of huPBMCs and m3s193 BsAb. The result showed that only less than $0.4 \%$ CD69-positive $\mathrm{T}$ cells in $\mathrm{CD}^{+}$and $\mathrm{CD}^{+} \mathrm{T}$ cells was detected even at a concentration of $1000 \mathrm{ng} / \mathrm{mL}$ of m3s193 BsAb (Figure S2a,b). Both CD8 ${ }^{+}$and $\mathrm{CD}^{+} \mathrm{T}$ cells play critical roles in preventing the body from pathogens in the immune system. Thus, m3s193 BsAb rather than m3s193 $\mathrm{mAb}$ and M971 BsAb could activate the T cells to lead potent in vitro cytotoxicity.

$\mathbf{a}$
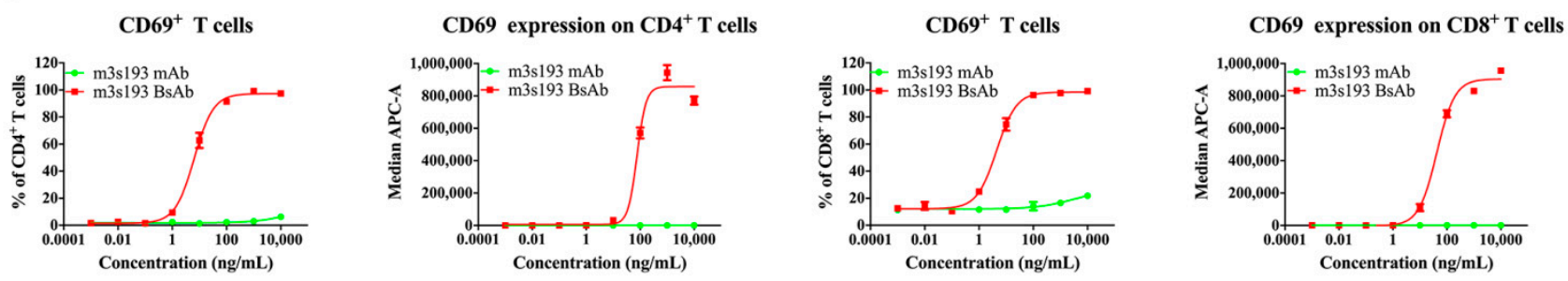

$\mathbf{b}$
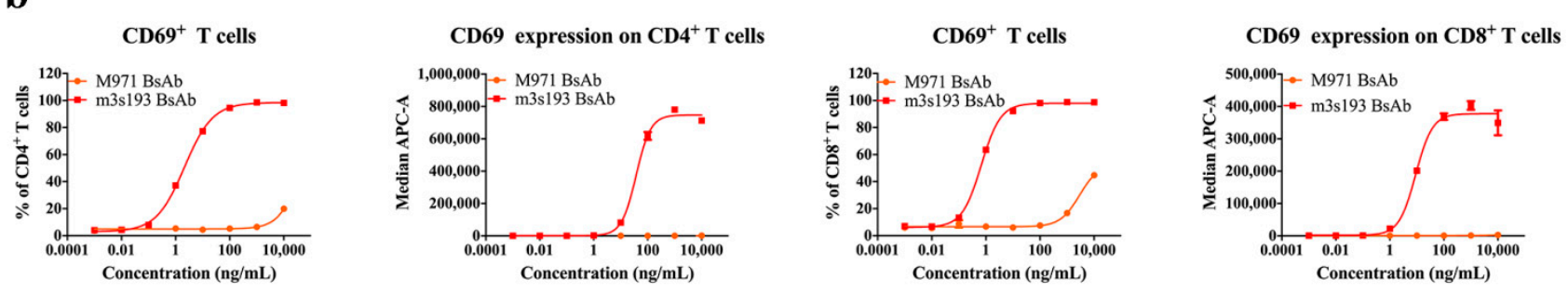

C
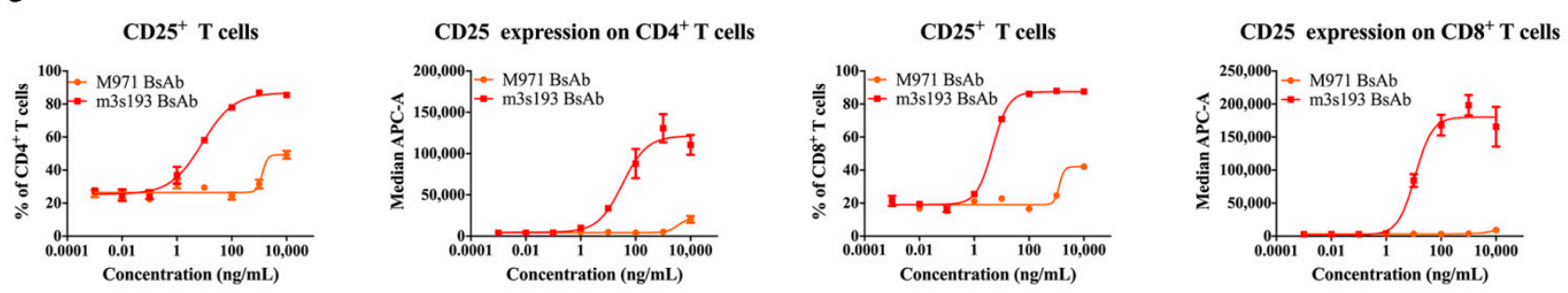

Figure 3. Activation of CD69 and CD25 expression on $\mathrm{CD}^{+}$and $\mathrm{CD} 4^{+} \mathrm{T}$ cells. The expression frequency and intensity of CD69 or CD25 on CD8 ${ }^{+}$and CD4 ${ }^{+}$T cells after $20 \mathrm{~h} \mathrm{(a,b)} \mathrm{or} 90 \mathrm{~h}(\mathbf{c})$ of co-incubation of NCI-N87 cells and huPBMCs. Data are shown as means $\pm \mathrm{SD}$ with three duplicates.

\subsection{Cytokine Release, Proliferation, and Recruiting Mediated by m3s193 BsAb}

Cancer immunotherapy by cytokines has been confirmed by a number of reports $[42,43]$. To evaluate if cytokines were released upon T cell activation by m3s193 BsAb, IL-2 and IFN- $\gamma$ detection assays were performed after T cell activation. Compared with control $\mathrm{mAb}$ and M971 BsAb, m3s193 BsAb could induce IL-2 and IFN- $\gamma$ release but not controls (Figure $4 \mathrm{a}, \mathrm{b}$ ). This result also proved that m3s193 BsAb had a strong anti-tumor activity by the release of IL-2 and IFN- $\gamma$ from huPBMCs to proliferate T cells and kill tumor cells. In contrast, there was no non-specific cytokine release and cell killing to Lewis $Y$ negative expression cells (Figures 2c and $4 b$ ). 
$\mathbf{a}$

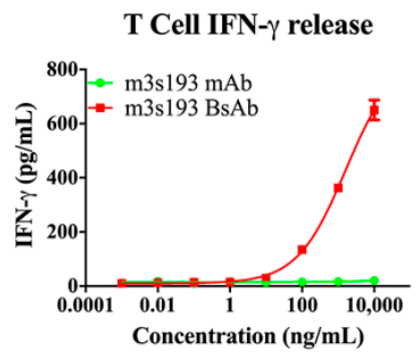

b

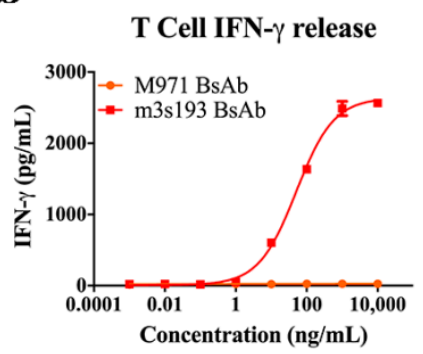

c

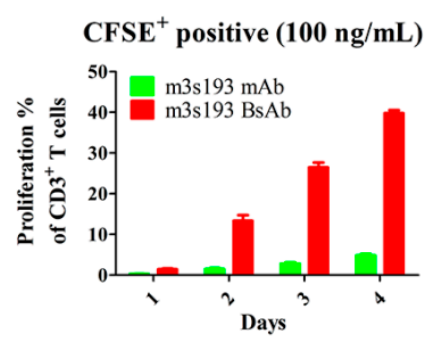

T Cell IL-2 release

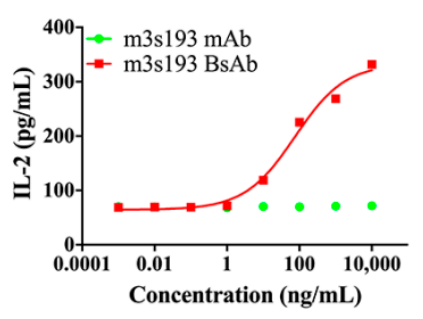

T Cell IL-2 release

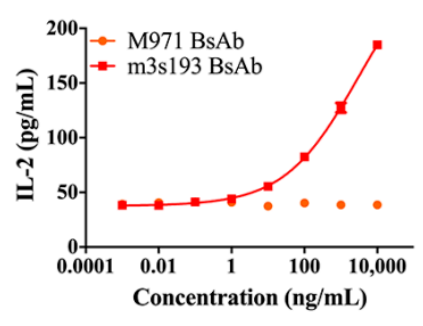

d

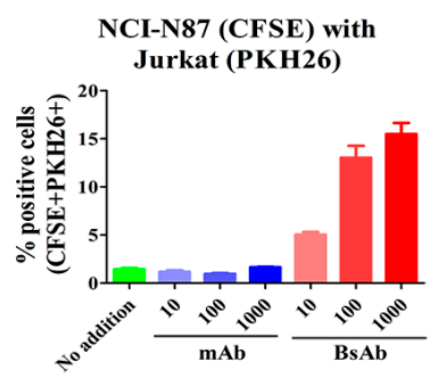

Figure 4. Cytokines release, proliferation, and recruiting mediated by m3s193 BsAb. (a) Cytokines release after $20 \mathrm{~h}$ incubation. (b) Cytokines release after $25 \mathrm{~h}$ incubation. (c) Proliferation of $\mathrm{CD}^{+} \mathrm{T}$ cells with $100 \mathrm{ng} / \mathrm{mL}$ of m3s193 BsAb or mAb. (d) Cell-cell association mediated by m3s193 BsAb or $\mathrm{mAb}$. Data are shown as means $\pm \mathrm{SD}$ with three duplicates.

We also found that m3s193 $\mathrm{BsAb}$ could induce $\mathrm{CD}^{+} \mathrm{T}$ cell proliferation from $10 \%$ to $40 \%$ after 2 to 4 days of incubation, while the control mAb only reached less than $5 \%$ proliferation percentage even at the fourth day (Figure 4c). This might be due to the proliferation signaling to T cells mediated by IL-2 which were released by T cell-engaging BsAb activation [44].

$\mathrm{T}$ cell-engaging BsAb could recruit $\mathrm{T}$ cells into the tumor micro-environment to form the immune synapse and then activate $T$ cells to release cytokines, granzyme, and perforin to kill tumor cells [45]. Thus, we used Jurkat cells instead of T cells due to CD3 expression on its surface to evaluate the recruiting ability of m3s193 BsAb. We found that m3s193 BsAb could mediate strong cell-cell association from the concentration of 10 to $1000 \mathrm{ng} / \mathrm{mL}$, while m3s193 mAb appeared similar to the group of "No addition" (Figure 4d). This result indicated that m3s193 BsAb rather than m3s193 mAb could recruit T cells to tumor cells in the in vitro activity assessment, which provided the potential of $\mathrm{T}$ cell infiltration into the tumor micro-environment in vivo. 


\subsection{In Vivo Anti-Tumor Activity}

\subsubsection{Tumor Inhibitory Activity of m3s193 BsAb}

To evaluate anti-tumor activity in vivo, the gastric cancer cell line NCI-N87 was inoculated in the huPBMCs/tumor co-grafting model with two drug delivery procedures in the assessment of m3s193 BsAb. From this initial study, we found that m3s193 BsAb had excellent anti-tumor activity compared with control group PBS in both drug delivery procedures (Figure $5 \mathrm{a}, \mathrm{e}$ ). In the first, twice a week delivery, the body weight of mice had no fluctuation between mice in both the testing group and control group (Figure $5 b$ ). In the second, continuous delivery, body weight fluctuations both in PBS and m3s193 BsAb groups were observed (Figure $5 \mathrm{f}$ ). The differences in the changes of weight in mice due to continuous drug delivery suggested interval drug delivery for the following in vivo activity evaluation. Tumor size and weight in the m3s193 BsAb group also proved potent anti-tumor activity in both delivery procedures (Figure $5 \mathrm{c}, \mathrm{d}, \mathrm{g}, \mathrm{h}$ ). All these data suggested that m3s193 BsAb had strong anti-tumor activity for eliminating tumors with no obvious toxicity in mice.

\section{$\mathbf{a}$}
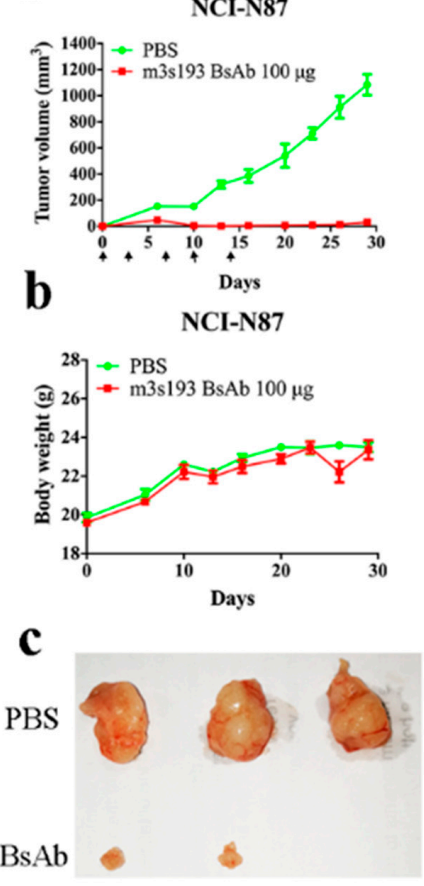

d

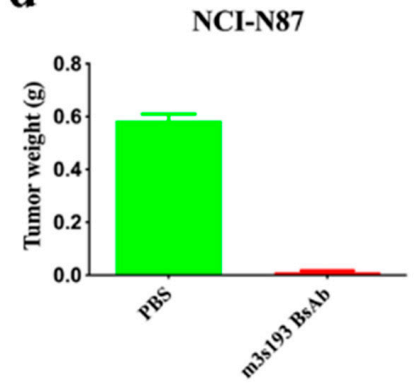

\section{$\mathbf{e}$}
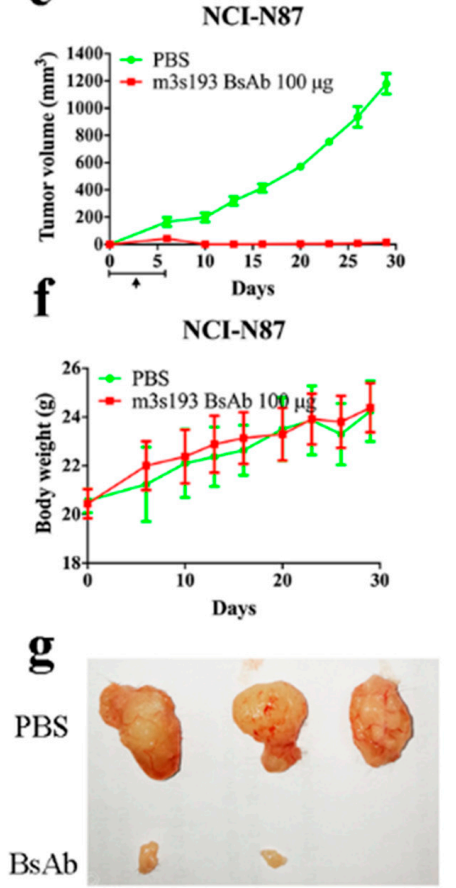

h

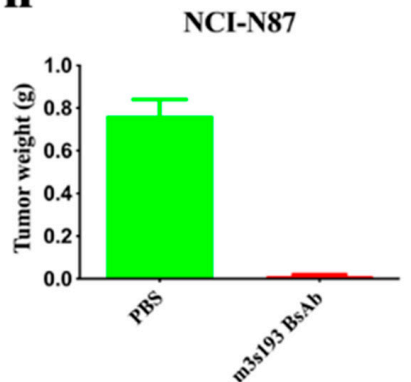

Figure 5. In vivo anti-tumor activity of m3s193 BsAb. Mice were treated i.v. with PBS $(n=3)$ and $100 \mu \mathrm{g}$ dosage of m3s193 BsAb $(n=5)$. (a-d) Mice were treated on day 0, twice a week, 5 times. (e-h) Mice were treated on day 0-6, 7 times. (a,e) Tumor growth curve plotted according to tumor volume and time. Black arrows indicate the time of therapy. $(\mathbf{b}, \mathbf{f})$ Mice body weight variation with time course. $(\mathbf{c}, \mathbf{g})$ The digital image of stripped tumors at study termination. $(\mathbf{d}, \mathbf{h})$ Tumor weight in two groups. Data are presented as mean \pm SD. 


\subsubsection{Remarkable Tumor Inhibitory Activity of m3s193 BsAb}

In vivo anti-tumor activity was further evaluated with various dosages of m3s193 BsAb compared with m3s193 mAb. BsAb m3s193 could significantly inhibit tumor growth with dose dependency (Figure 6a), while m3s193 mAb did not inhibit tumor growth at $20 \mu \mathrm{g}$ dosage close to the "PBS group" $(p>0.05)$ (Figure 6b). Mean tumor growth curve and tumor size image also revealed potent anti-tumor activity of m3s193 BsAb under various dosages with significant $p$ value (Figure $6 \mathrm{~b}, \mathrm{c}$ ). There were no body weight differences among five groups, suggesting that m3s193 BsAb had a minimum toxicity (Figure 6d). On the other hand, tumor weight reducing in the BsAb group showed better inhibitory tumor activity of m3s193 BsAb than the parent $\mathrm{mAb}$ (Figure 6e). These data illustrated that systematic administration of m3s193 BsAb could inhibit the Lewis Y-expressing NCI-N87 xenograft tumor growth compared with the parent $\mathrm{mAb}$. By immune-histochemical assay, there was no existence of $\mathrm{CD} 8^{+}$and $\mathrm{CD} 4^{+} \mathrm{T}$ cells in the tumor micro-environment in the $\mathrm{PBS}$ and $\mathrm{mAb}(20 \mu \mathrm{g})$ groups, but there was existence in the BsAb $(20 \mu \mathrm{g})$ group (Figure $6 \mathrm{f})$, which suggested that $\mathrm{T}$ cells, particularly for $\mathrm{CD}^{+}$and $\mathrm{CD} 4^{+} \mathrm{T}$ cells, could survive for a long time when activated by m3s193 BsAb. This could be one of the reasons for inhibiting tumor growth in the m3s193 BsAb group.
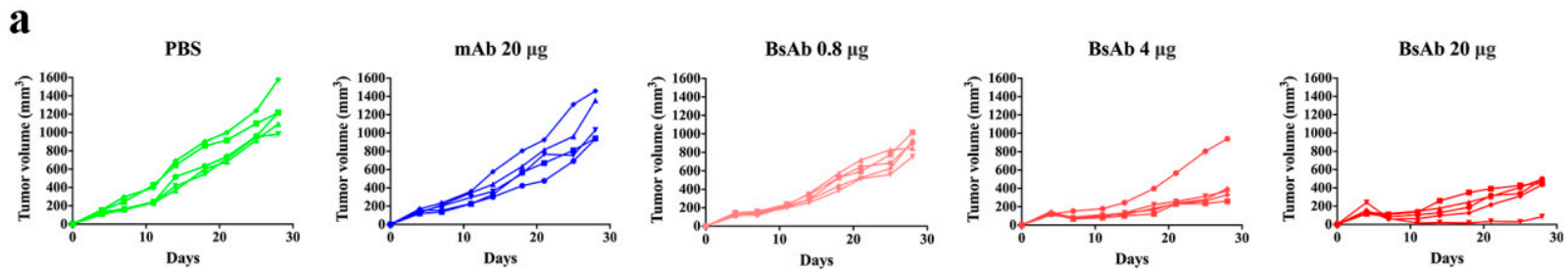

b

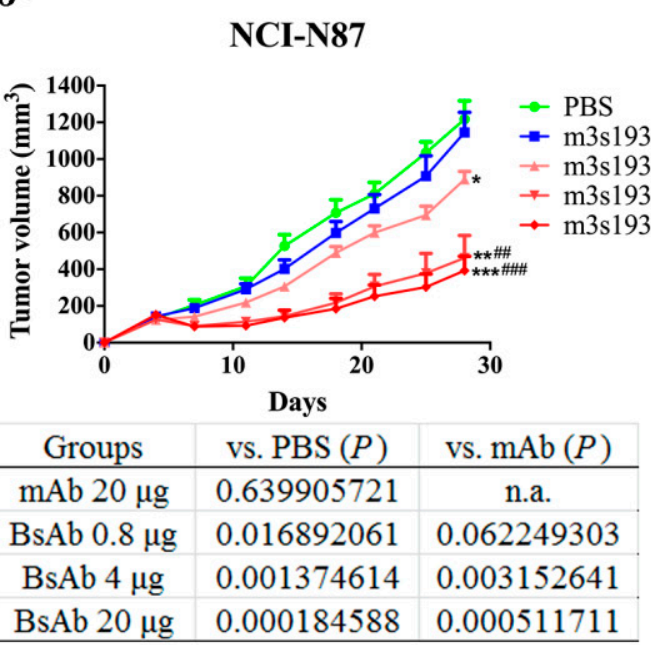

d

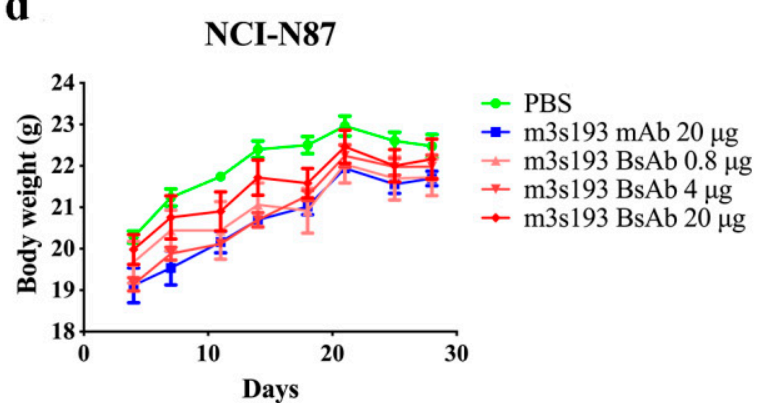

c

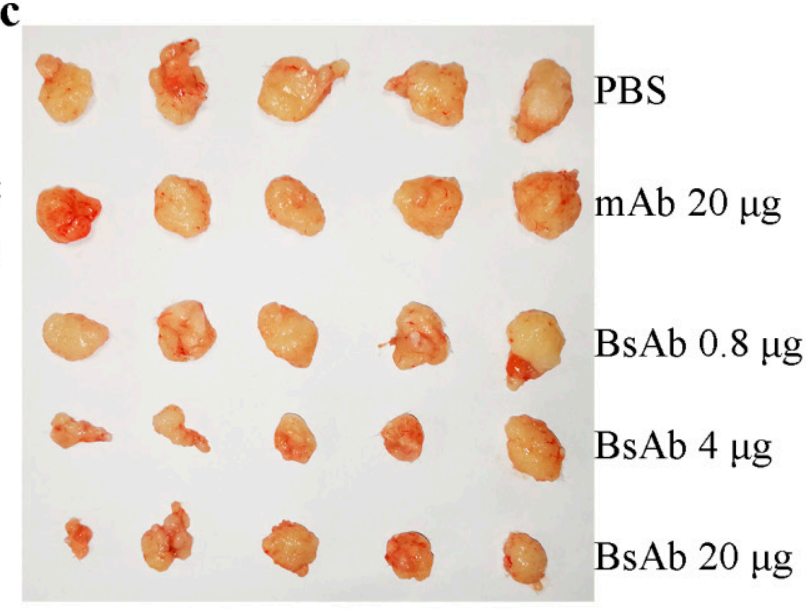

e

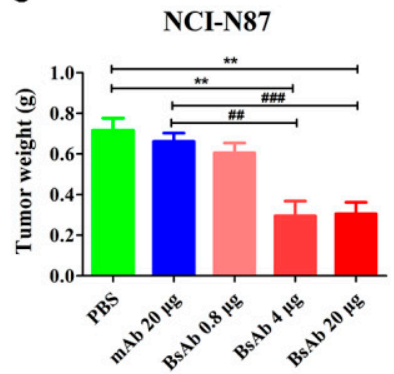

Figure 6. Cont. 


\section{f}

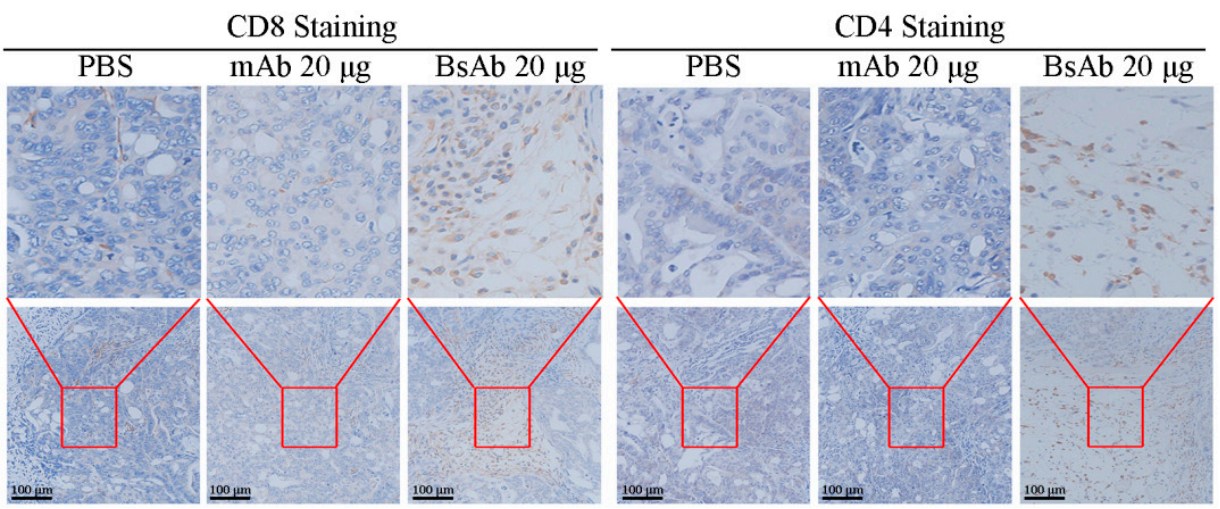

Figure 6. In vivo anti-tumor activity of m3s193 mAb and m3s193 BsAb. Mice were treated i.v. with PBS, mAb (20 $\mu \mathrm{g})$, and $\mathrm{BsAb}(0.8,4,20 \mu \mathrm{g})$ on day 0, twice a week, 6 times. (a) Individual tumor growth curve with time course. Data are presented as measured tumor volume from each mouse in five groups. (b) Mean tumor growth curve with time course. Data are presented as mean $\pm \mathrm{SD}$. Statistical significance of experiment groups compared to PBS and mAb group was analyzed by Student's t-test with two-tailed double sample isovariance hypothesis in Microsoft Excel, and $p<0.05$ was considered statistically significant. (c) The digital image of stripped tumors. (d) Mice body weight of five groups with time course and presented as mean \pm SD. (e) Weight of stripped tumors in five groups and presented as mean \pm SD. Differences between samples were also tested for statistical significance by the same Student's t-test. (f) Representative images of histologic analysis of explanted tumors stained for human CD8 and CD4. In this figure, ${ }^{*}, * *$, and ${ }^{* * *}$ mean compared with the PBS group, ${ }^{*} p<0.05,{ }^{* *} p<0.01$, and ${ }^{* * *} p<0.001$. \#\#, and \#\#\# mean compared with the mAb group, \#\# $p<0.01$, and $\# \#$ \# $p<0.001$.

\subsubsection{M3s193 BsAb Had Potent Anti-Tumor Activity in Therapeutic Study}

In the tumor/huPBMCs co-grafting animal model, m3s193 BsAb could inhibit tumor growth and had much stronger anti-tumor activity than m3s193 mAb. In this model, huPBMCs were mixed with tumor cells and were forcedly infiltrated by human factor. Under normal physiological conditions, in the tumor micro-environment where some tumors, especially non-immunoreactive tumors, were, $\mathrm{T}$ cells only had a very low level or almost did not exist $[46,47]$. To mimic this condition, we performed the therapeutic study by only subcutaneously implanting tumor cells into mice before huPBMCs and therapy administration were injected. First, we detected the reconstruction of huPBMCs in NOG mice and found that all mice $(n=16)$ were successfully reconstructed with about $20-60 \%$ of huCD45 cells in mice peripheral blood after fourteen days of huPBMCs transfer (Figure 7a), which ensured that all mice could be used for the effectiveness evaluation of m3s193 BsAb. From the tumor growth curve, m3s193 BsAb could eliminate tumors even though the tumor volume reached about $600 \mathrm{~mm}^{3}$ (Figure $7 \mathrm{~b}, \mathrm{c}$ ). All tumors in the m3s193 BsAb group were much smaller when tumors were stripped after study termination (Figure $7 \mathrm{~d}$ ). The mean weight of stripped tumors in the m3s193 BsAb group further confirmed this result (Figure 7e). These data suggested that $\mathrm{m} 3 \mathrm{~s} 193 \mathrm{BsAb}$ could eliminate tumors in vivo by huPBMCs reconstruction in mice. Immune-histochemical results revealed that $\mathrm{CD}^{+} \mathrm{T}$ cells existed in the PBS group and were mainly around tumor stroma (red oval circle) (Figure 7f). In the m3s193 BsAb group, there was only a small residual tumor tissue (yellow oval circle) surrounded by $\mathrm{T}$ cells, which illustrated that $\mathrm{m} 3 \mathrm{~s} 193 \mathrm{BsAb}$ could mediate the infiltration of $\mathrm{T}$ cells derived from peripheral blood into the tumor micro-environment. This result could explain the reason for tumor elimination in the m3s193 BaAb group by mediating $\mathrm{T}$ cell infiltration. 
a
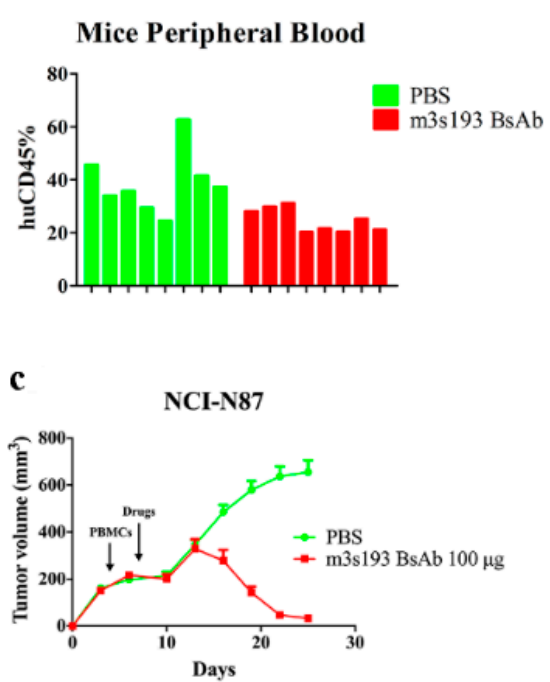

f

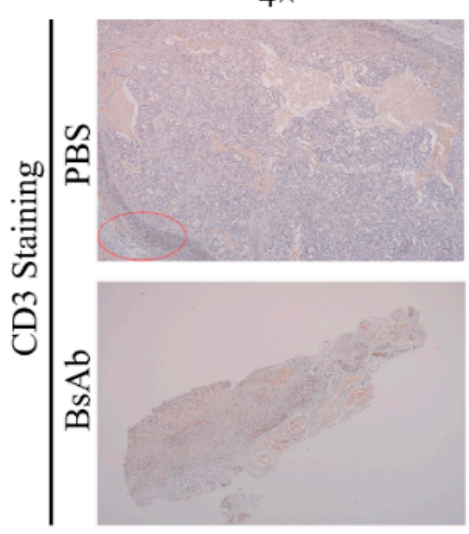

b

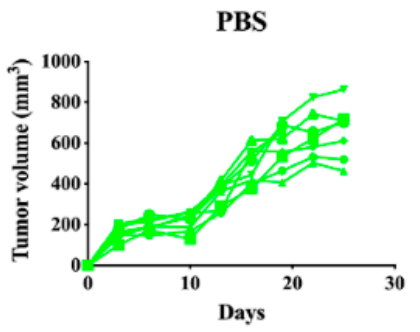

d

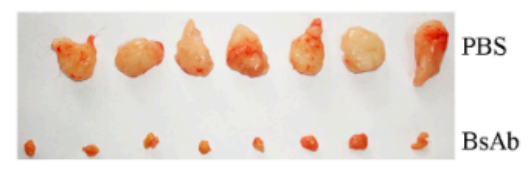

$10 \times$

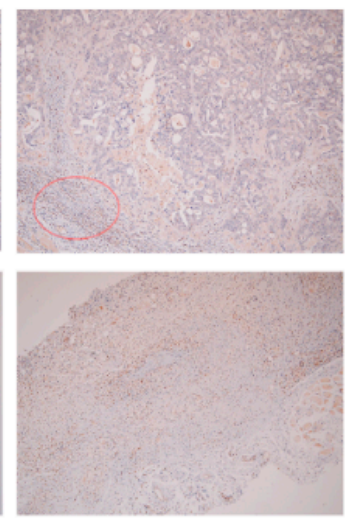

$20 \times$

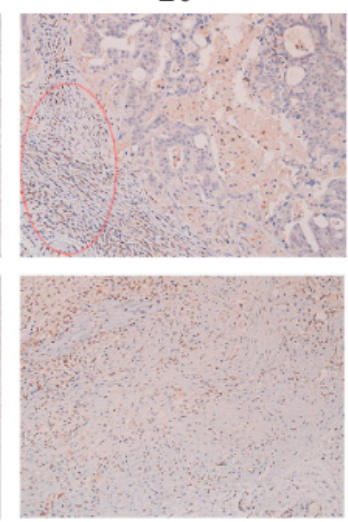

BsAb $100 \mu \mathrm{g}$

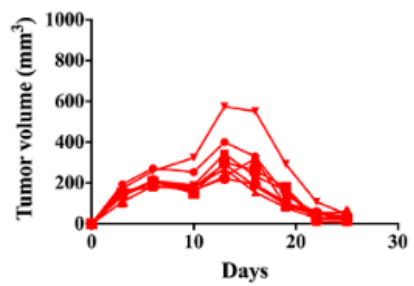

e

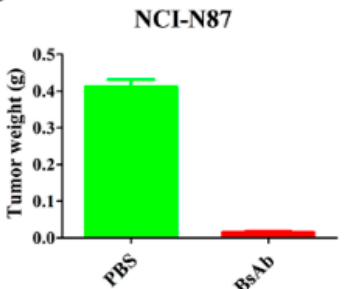

Figure 7. In vivo anti-tumor activity of m3s193 BsAb with i.v. transfer of huPBMCs. (a) Flow-cytometry analysis of huCD45 ${ }^{+}$ cells in mice peripheral blood. (b) Individual tumor growth curve with time course. Data are presented as measured tumor volume from each mouse in two groups. (c) Mean tumor growth curve with time course. Data are presented as mean \pm SD. (d) The digital image of stripped tumors. (e) Weight of stripped tumors and presented as mean \pm SD. (f) Representative images of histologic analysis of explanted tumors stained for human CD3. Red oval circle represents infiltrated huPBMCs around tumor stroma in PBS group, and yellow oval circle represents residual tumor tissue surrounded by infiltrated huPBMCs in BsAb group.

\section{Discussion}

Bispecific antibody (BsAb) plays an important role in immunotherapy for cancer and other diseases. In this report, we constructed a novel T cell-engaging BsAb targeting Lewis $\mathrm{Y}$ and CD3 antigen to evaluate anti-tumor activity for the first time. The BsAb (m3s193 BsAb) had similar binding affinity to Lewis $\mathrm{Y}$ positive cancer cell lines compared to its parent $\mathrm{mAb}$, due to the IgG-[L]-scfv structure keeping two Fab binding domains of normal antibody. Experimental results revealed that m3s193 BsAb could activate CD69 and CD25 expression on T cells and induced cytokine release to mediate cytotoxicity in vitro. Although Lewis $Y$ was expressed on granulocytes in peripheral blood, m3s193 BsAb could not activate $\mathrm{CD}^{+}$and $\mathrm{CD} 4^{+} \mathrm{T}$ cells with CD69 expression when only co-incubated with huPBMCs in the absence of target cells (Figure S2 a,b). These data further indicated the specificity of IgG-[L]-scfv-derived T cell-engaging BsAbs with two binding scfvs of antiCD3. Besides activation, m3s193 BsAb, rather than the control mAb, could mediate cell-cell association, which validated the basic function of $\mathrm{T}$ cell-engaging BsAbs, as reported 
previously [48]. By shortening distance between T cells and tumor cells, T cell-engaging BsAbs could mediate the formation of an immune synapse to activate T cells [49]. Thus, a closer distance is mandatory for a proper induction of T cell activation [50].

In both drug delivery procedures in the animal in vivo study, m3s193 BsAb could significantly inhibit tumor growth with no body weight fluctuation in a twice-a-week delivery procedure, suggesting that interval therapy was suitable in the following in vivo experiment (Figure 5). In following the tumor/huPBMCs co-grafting model, m3s193 BsAb performed a similar tumor inhibitory activity with dose dependency, while the control $\mathrm{mAb}$ did not show activity at the high dosage, which was due to the existence of $\mathrm{CD} 8^{+}$and $\mathrm{CD}^{+} \mathrm{T}$ cells in the tumor micro-environment mediated by BsAb (Figure 6). M3s193 BsAb also eliminated large size tumors $\left(600 \mathrm{~mm}^{3}\right)$ in mice by inducing $\mathrm{CD}^{+} \mathrm{T}$ cell infiltration, as previously reported in a similar solid tumor treatment by carcinoembryoin antigen $\mathrm{T}$ cell-engaging BsAb [51,52].

Targeting tumor-association glycan would be a potential therapy strategy due to its fundamental and crucial physiological functions in the genesis and development of cancers [53]. In addition to Lewis $Y$, several therapies targeting glycan neo-antigens have been in clinical trials, such as monosialodihexosylganglioside (GM3 containing Neu5Gc), gangliosides (GD3 and GD2), and Tn glycoform of MUC1 [54-57]. Thus, this work not only provided a new therapy targeting Lewis $Y$ to make up for the deficiency of $m A b$ therapy but also illustrated that targeting tumor glycan-antigen would contribute to a new era of cancer-targeted therapy where BsAbs may play a potentially crucial role.

\section{Conclusions}

Our findings provide more meaningful evidence for the treatment of gastric cancer by targeting a tumor-associated glycan-antigen. All these data support the idea that the Lewis $\mathrm{Y}$ target could be developed into a preclinical anti-tumor study by redirecting $\mathrm{T}$ cells to activate the immune response.

Supplementary Materials: The following are available online at https:/ /www.mdpi.com/article/10 .3390 /biomedicines9081059/s1, Figure S1: SEC-HPLC analysis of m3s193 mAb, m3s193 BsAb, and M971 BsAb, Figure S2: Auto-activation of huPBMCs mediated by m3s193 BsAb.

Author Contributions: Conceptualization, J.C. and J.Z.; data curation, J.C., B.Z. and J.Z.; formal analysis, J.C., Z.P., L.H., Y.Z. and H.Z.; funding acquisition, Y.Y. and J.Z.; methodology, J.C., L.W. and R.S.; project administration, J.C., B.Z. and J.Z.; resources, J.Z.; supervision, B.Z. and J.Z.; validation, J.C. and J.Z.; visualization, J.C. and J.Z.; writing —original draft, J.C.; writing—review and editing, J.C., M.W., Y.B., H.J., Y.X. and J.Z. All authors have read and agreed to the published version of the manuscript.

Funding: This work was supported by the National Natural Science Foundation of China (J.Z., No. 81773621 and 82073751) and the National Science and Technology Major Project "Key New Drug Creation and Manufacturing Program" of China (J.Z., No.2019ZX09732001-019, and Y.Y., No. 2019ZX09201001).

Institutional Review Board Statement: The mice in the study were handled according to guidelines from the Institutional Animal Care and Use Committee of the School of Pharmacy of Shanghai Jiao Tong University.

Informed Consent Statement: Not applicable.

Data Availability Statement: The dataset supporting the conclusions of this article is included within the article.

Acknowledgments: We offer thanks for the technical support from Jecho Biopharmaceuticals Co., Ltd., and Jecho Laboratories, Inc.

Conflicts of Interest: The authors declare no conflict of interest. 


\section{References}

1. Labrijn, A.F.; Janmaat, M.L.; Reichert, J.M.; Parren, P.W. Bispecific antibodies: A mechanistic review of the pipeline. Nat. Rev. Drug Discov. 2019, 18, 585-608. [CrossRef]

2. Haas, C.; Krinner, E.; Brischwein, K.; Hoffmann, P.; Lutterbüse, R.; Schlereth, B.; Kufer, P.; Baeuerle, P.A. Mode of cytotoxic action of T cell-engaging BiTE antibody MT110. Immunobiology 2009, 214, 441-453. [CrossRef] [PubMed]

3. Stadler, C.R.; Bähr-Mahmud, H.; Plum, L.M.; Schmoldt, K.; Kölsch, A.C.; Türeci, Ö.; Sahin, U. Characterization of the first-in-class T-cell-engaging bispecific single-chain antibody for targeted immunotherapy of solid tumors expressing the oncofetal protein claudin 6. OncoImmunology 2015, 5, e1091555. [CrossRef]

4. Wu, Z.; Cheung, N. T cell engaging bispecific antibody (T-BsAb): From technology to therapeutics. Pharmacol. Ther. 2018, 182, 161-175. [CrossRef] [PubMed]

5. Liu, L.; Lam, C.-Y.K.; Long, V.; Widjaja, L.; Yang, Y.; Li, H.; Jin, L.; Burke, S.; Gorlatov, S.; Brown, J.; et al. MGD011, A CD19 x CD3 Dual-Affinity Retargeting Bi-specific Molecule Incorporating Extended Circulating Half-life for the Treatment of B-Cell Malignancies. Clin. Cancer Res. 2017, 23, 1506-1518. [CrossRef]

6. Lopez-Albaitero, A.; Xu, H.; Guo, H.; Wang, L.; Wu, Z.; Tran, H.; Chandarlapaty, S.; Scaltriti, M.; Janjigian, Y.; De Stanchina, E.; et al. Overcoming resistance to HER2-targeted therapy with a novel HER2/CD 3 bispecific antibody. OncoImmunology 2017, 6, e1267891. [CrossRef] [PubMed]

7. Santich, B.H.; Park, J.A.; Tran, H.; Guo, H.-F.; Huse, M.; Cheung, N.-K.V. Interdomain spacing and spatial configuration drive the potency of IgG-[L]-scFv T cell bispecific antibodies. Sci. Transl. Med. 2020, 12, eaax1315. [CrossRef] [PubMed]

8. Hokke, C.H.; Neeleman, A.P.; Koeleman, C.A.; van den Eijnden, D.H. Identification of an alpha3-fucosyltransferase and a novel alpha2-fucosyltransferase activity in cercariae of the schistosome Trichobilharzia ocellata: Biosynthesis of the Fucalpha1$>$ 2Fucalpha1->3[Gal(NAc)beta1->4]GlcNAc sequence. Glycobiology 1998, 8, 393-406. [CrossRef] [PubMed]

9. Kitamura, K.; Stockert, E.; Garin-Chesa, P.; Welt, S.; Lloyd, K.O.; Armour, K.L.; Wallace, T.P.; Harris, W.J.; Carr, F.J.; Old, L.J. Specificity analysis of blood group Lewis-y (Le(y)) antibodies generatedagainst synthetic and natural Le(y) determinants. Proc. Natl. Acad. Sci. USA 1994, 91, 12957-12961. [CrossRef] [PubMed]

10. Westwood, J.A.; Smyth, M.J.; Teng, M.W.L.; Moeller, M.; Trapani, J.A.; Scott, A.M.; Smyth, F.E.; Cartwright, G.A.; Power, B.E.; Hönemann, D.; et al. Adoptive transfer of T cells modified with a humanized chimeric receptor gene inhibits growth of Lewis-Y-expressing tumors in mice. Proc. Natl. Acad. Sci. USA 2005, 102, 19051-19056. [CrossRef]

11. Scott, A.M.; Geleick, D.; Rubira, M.; Clarke, K.; Nice, E.C.; Smyth, F.E.; Stockert, E.; Richards, E.C.; Carr, F.J.; Harris, W.J.; et al. Construction, production, and characterization of humanized anti-Lewis Y monoclonal antibody $3 S 193$ for targeted immunotherapy of solid tumors. Cancer Res. 2000, 60, 3254-3261. [PubMed]

12. Dettke, M.; Pálfi, G.; Loibner, H. Activation-dependent expression of the blood group-related lewis $Y$ antigen on peripheral blood granulocytes. J. Leukoc. Biol. 2000, 68, 511-514. [PubMed]

13. Klinger, M.; Farhan, H.; Just, H.; Drobny, H.; Himmler, G.; Loibner, H.; Mudde, G.C.; Freissmuth, M.; Sexl, V. Antibodies directed against Lewis-Y antigen inhibit signaling of Lewis-Y modified ErbB receptors. Cancer Res. 2004, 64, 1087-1093. [CrossRef] [PubMed]

14. Tan, M.; Zhu, L.; Zhuang, H.; Hao, Y.; Gao, S.; Liu, S.; Liu, Q.; Liu, D.; Liu, J.; Lin, B. Lewis Y antigen modified CD47 is an independent risk factor for poor prognosis and promotes early ovarian cancer metastasis. Am. J. Cancer Res. $2015,5,2777-2787$.

15. Gao, L.; Yan, L.; Lin, B.; Gao, J.; Liang, X.; Wang, Y.; Liu, J.; Zhang, S.; Masao, I. Enhancive effects of Lewis y antigen on CD44-mediated adhesion and spreading of human ovarian cancer cell line RMG-I. J. Exp. Clin. Cancer Res. 2011, 30, 15. [CrossRef] [PubMed]

16. Gao, J.; Hu, Z.; Liu, J.; Liu, D.; Wang, Y.; Cai, M.; Zhang, D.; Tan, M.; Lin, B. Expression of CD147 and Lewis y antigen in ovarian cancer and their relationship to drug resistance. Med. Oncol. 2014, 31, 920. [CrossRef]

17. Hellström, I.; Garrigues, H.J.; Garrigues, U.; Hellström, K.E. Highly tumor-reactive, internalizing, mouse monoclonal antibodies to Le(y)-related cell surface antigens. Cancer Res. 1990, 50, 2183-2190.

18. Zhang, S.; Zhang, H.S.; Cordon-Cardo, C.; Reuter, V.E.; Singhal, A.K.; Lloyd, K.O.; Livingston, P.O. Selection of tumor antigens as targets for immune attack using immunohistochemistry: II. Blood group-related antigens. Int. J. Cancer 1997, 73, 50-56. [CrossRef]

19. Madjd, Z.; Parsons, T.; Watson, N.F.; Spendlove, I.; Ellis, I.; Durrant, L.G. High expression of Lewisy/bantigens is associated with decreased survival in lymph node negative breast carcinomas. Breast Cancer Res. 2005, 7, R780-R787. [CrossRef]

20. Wang, Y.; Liu, J.; Lin, B.; Wang, C.; Li, Q.; Liu, S.; Yan, L.; Zhang, S.; Iwamori, M. Study on the Expression and Clinical Significances of Lewis y Antigen and Integrin $\alpha \mathrm{v}, \beta 3$ in Epithelial Ovarian Tumors. Int. J. Mol. Sci. 2011, 12, 3409-3421. [CrossRef]

21. Liu, J.-J.; Lin, B.; Hao, Y.-Y.; Li, F.-F.; Liu, D.-W.; Qi, Y.; Zhu, L.-C.; Zhang, S.-L.; Iwamori, M. Lewis(y) antigen stimulates the growth of ovarian cancer cells via regulation of the epidermal growth factor receptor pathway. Oncol. Rep. 2010, $23,833-841$. [PubMed]

22. Liu, J.; Lin, B.; Hao, Y.; Qi, Y.; Zhu, L.; Li, F.; Liu, D.; Cong, J.; Zhang, S.; Iwamori, M. Lewis y antigen promotes the proliferation of ovarian carcinoma-derived RMG-I cells through the PI3K/Akt signaling pathway. J. Exp. Clin. Cancer Res. 2009, $28,154$. [CrossRef] [PubMed]

23. Li, Q.; Liu, S.; Lin, B.; Yan, L.; Wang, Y.; Wang, C.; Zhang, S. Expression and correlation of Lewis y antigen and integrins ?5 and ?1 in ovarian serous and mucinous carcinoma. Int. J. Gynecol. Cancer 2010, 20, 1482-1489. [CrossRef] 
24. Gao, J.; Hu, Z.; Liu, D.; Liu, J.; Liu, C.; Hou, R.; Gao, S.; Zhang, D.; Zhang, S.; Lin, B. Expression of Lewis y antigen and integrin $\alpha \mathrm{v}, \beta 3$ in ovarian cancer and their relationship with chemotherapeutic drug resistance. J. Exp. Clin. Cancer Res. 2013, 32, 36. [CrossRef] [PubMed]

25. Hu, Z.; Gao, S.; Gao, J.; Hou, R.; Liu, C.; Liu, J.; Li, B.; Liu, D.; Zhang, S.; Lin, B. Elevated Levels of Lewis Y and Integrin $\alpha 5 \beta 1$ Correlate with Chemotherapeutic Drug Resistance in Epithelial Ovarian Carcinoma. Int. J. Mol. Sci. 2012, 13, 15588-15600. [CrossRef]

26. Baldus, S.E.; Mönig, S.P.; Zirbes, T.K.; Thakran, J.; Köthe, D.; Köppel, M.; Hanisch, F.-G.; Thiele, J.; Schneider, P.M.; Hölscher, A.H.; et al. Lewis(y) antigen (CD174) and apoptosis in gastric and colorectal carcinomas: Correlations with clinical and prognostic parameters. Histol. Histopathol. 2006, 21, 503-510. [PubMed]

27. Clarke, K.; Lee, F.T.; Brechbiel, M.W.; Smyth, F.E.; Old, L.J.; Scott, A.M. Therapeutic efficacy of anti-Lewis(y) humanized $3 S 193$ radioimmunotherapy in a breast cancer model: Enhanced activity when combined with taxol chemotherapy. Clin. Cancer Res. 2000, 6, 3621-3628. [PubMed]

28. Aziz, F.; Yang, X.; Wang, X.; Yan, Q. Anti-LeY antibody enhances therapeutic efficacy of celecoxib against gastric cancer by downregulation of MAPKs/COX-2 signaling pathway: Correlation with clinical study. J. Cancer Res. Clin. Oncol. 2014, 141, 1221-1235. [CrossRef]

29. Kawai, S.; Kato, S.; Imai, H.; Okada, Y.; Ishioka, C. Suppression of FUT1 attenuates cell proliferation in the HER2-overexpressing cancer cell line NCI-N87. Oncol. Rep. 2012, 29, 13-20. [CrossRef]

30. Smaletz, O.; Diz, M.D.; do Carmo, C.C.; Sabbaga, J.; Cunha-Junior, G.F.; Azevedo, S.J.; Maluf, F.C.; Barrios, C.H.; Costa, R.L.; Fontana, A.G.; et al. A phase II trial with anti-Lewis-Y monoclonal antibody (hu3S193) for the treatment of platinum resistant/refractory ovarian, fallopian tube and primary peritoneal carcinoma. Gynecol. Oncol. 2015, 138, 272-277. [CrossRef]

31. Smaletz, O.; Ismael, G.; Del Pilar Estevez-Diz, M.; O Nascimento, I.L.O.; de Morais, A.L.G.; Cunha-Junior, G.F.; Azevedo, S.J.; Alves, V.A.; Moro, A.M.; Yeda, F.P.; et al. Phase II consolidation trial with anti-Lewis-Y monoclonal antibody (hu3S193) in platinum-sensitive ovarian cancer after a second remission. Int. J. Gynecol. Cancer 2021, 31, 562-568. [CrossRef]

32. Han, L.; Chen, J.; Ding, K.; Zong, H.; Xie, Y.; Jiang, H.; Zhang, B.; Lu, H.; Yin, W.; Gilly, J.; et al. Efficient generation of bispecific IgG antibodies by split intein mediated protein trans-splicing system. Sci. Rep. 2017, 7, 8360. [CrossRef]

33. Xu, H.; Cheng, M.; Guo, H.; Chen, Y.; Huse, M.; Cheung, N.-K.V. Retargeting T Cells to GD2 Pentasaccharide on Human Tumors Using Bispecific Humanized Antibody. Cancer Immunol. Res. 2015, 3, 266-277. [CrossRef] [PubMed]

34. Wu, Z.; Guo, H.-F.; Xu, H.; Cheung, N.-K.V. Development of a tetravalent anti-GPA33/anti-CD3 bispecific antibody for colorectal cancers. Mol. Cancer Ther. 2018, 17, 2164-2175. [CrossRef] [PubMed]

35. Lo, M.; Kim, H.S.; Tong, R.K.; Bainbridge, T.W.; Vernes, J.-M.; Zhang, Y.; Lin, Y.L.; Chung, S.; Dennis, M.S.; Zuchero, Y.J.Y.; et al. Effector-attenuating Substitutions That Maintain Antibody Stability and Reduce Toxicity in Mice. J. Biol. Chem. 2017, 292, 3900-3908. [CrossRef] [PubMed]

36. Adair, J.R.; Athwal, D.S.; Bodmer, M.W.; Bright, S.M.; Collins, A.M.; Pulito, V.L.; Rao, P.E.; Reedman, R.; Rothermel, A.L.; Xu, D.; et al. Humanization of the murine anti-human CD3 monoclonal antibody OKT3. Hum. Antibodies 1994, 5, 41-47. [CrossRef]

37. Xiao, X.; Ho, M.; Zhu, Z.; Pastan, I.; Dimitrov, D.S. Identification and characterization of fully human anti-CD22 monoclonal antibodies. $m A$ s s 2009, 1, 297-303. [CrossRef]

38. Ding, K.; Han, L.; Zong, H.; Chen, J.; Zhang, B.; Zhu, J. Production process reproducibility and product quality consistency of transient gene expression in HEK293 cells with anti-PD1 antibody as the model protein. Appl. Microbiol. Biotechnol. 2017, 101, 1889-1898. [CrossRef]

39. Zhu, J. Mammalian cell protein expression for biopharmaceutical production. Biotechnol. Adv. 2012, 30, 1158-1170. [CrossRef]

40. Zhu, J. Update on Production of Recombinant Therapeutic Protein: Transient Gene Expression; Smithers Rapra: Shawbury, UK, 2013.

41. Fan, D.; Li, W.; Yang, Y.; Zhang, X.; Zhang, Q.; Yan, Y.; Yang, M.; Wang, J.; Xiong, D. Redirection of CD4 $4^{+}$and CD8 ${ }^{+}$T lymphocytes via an anti-CD3 $\times$ anti-CD19 bi-specific antibody combined with cytosine arabinoside and the efficient lysis of patient-derived B-ALL cells. J. Hematol. Oncol. 2015, 8, 108. [CrossRef]

42. Mohammad, G.R.K.S.; Ghahremanloo, A.; Soltani, A.; Fathi, E.; Hashemy, S.I. Cytokines as potential combination agents with PD-1/PD-L1 blockade for cancer treatment. J. Cell. Physiol. 2020, 235, 5449-5460. [CrossRef] [PubMed]

43. Conlon, K.C.; Miljković, M.; Waldmann, T.A. Cytokines in the Treatment of Cancer. J. Interf. Cytokine Res. 2019, 39, 6-21. [CrossRef]

44. Benczik, M.; Gaffen, S.L. The Interleukin (IL)-2 Family Cytokines: Survival and Proliferation Signaling Pathways in T Lymphocytes. Immunol. Investig. 2004, 33, 109-142. [CrossRef]

45. Sun, L.L.; Ellerman, D.; Mathieu, M.; Hristopoulos, M.; Chen, X.; Li, Y.; Yan, X.; Clark, R.; Reyes, A.; Stefanich, E.; et al. AntiCD20/CD3 T cell-dependent bispecific antibody for the treatment of B cell malignancies. Sci. Transl. Med. 2015, 7, 287ra70. [CrossRef] [PubMed]

46. Hanahan, D.; Weinberg, R.A. Hallmarks of Cancer: The Next Generation. Cell 2011, 144, 646-674. [CrossRef]

47. de Olza, M.O.; Rodrigo, B.N.; Zimmermann, S.; Coukos, G. Turning up the heat on non-immunoreactive tumours: Opportunities for clinical development. Lancet Oncol. 2020, 21, e419-e430. [CrossRef]

48. Zhou, Y.; Zong, H.; Han, L.; Xie, Y.; Jiang, H.; Gilly, J.; Zhang, B.; Lu, H.; Chen, J.; Sun, R.; et al. A novel bispecific antibody targeting CD3 and prolactin receptor (PRLR) against PRLR-expression breast cancer. J. Exp. Clin. Cancer Res. $2020,39,87$. [CrossRef] [PubMed] 
49. Dickopf, S.; Georges, G.J.; Brinkmann, U. Format and geometries matter: Structure-based design defines the functionality of bispecific antibodies. Comput. Struct. Biotechnol. J. 2020, 18, 1221-1227. [CrossRef] [PubMed]

50. Choudhuri, K.; Wiseman, D.; Brown, M.H.; Gould, K.; Van Der Merwe, P.A. T-cell receptor triggering is critically dependent on the dimensions of its peptide-MHC ligand. Nature 2005, 436, 578-582. [CrossRef]

51. Bacac, M.; Fauti, T.; Sam, J.; Colombetti, S.; Weinzierl, T.; Ouaret, D.; Bodmer, W.F.; Lehmann, S.; Hofer, T.; Hosse, R.J.; et al. A Novel Carcinoembryonic Antigen T-Cell Bispecific Antibody (CEA TCB) for the Treatment of Solid Tumors. Clin. Cancer Res. 2016, 22, 3286-3297. [CrossRef]

52. Bacac, M.; Klein, C.; Umana, P. CEA TCB: A novel head-to-tail 2:1 T cell bispecific antibody for treatment of CEA-positive solid tumors. OncoImmunology 2016, 5, e1203498. [CrossRef] [PubMed]

53. Varki, A.; Cummings, R.D.; Esko, J.D.; Stanley, P.; Hart, G.W.; Aebi, M.; Darvill, A.G.; Kinoshita, T.; Packer, N.H.; Prestegard, J.H.; et al. Essentials of Glycobiology; Cold Spring Harbor Laboratory Press: Cold Spring Harbor, NY, USA, 2015.

54. Labrada, M.; Dorvignit, D.; Hevia, G.; Rodríguez-Zhurbenko, N.; Hernández, A.M.; Vázquez, A.M.; Fernández, L.E. GM3(Neu5Gc) ganglioside: An evolution fixed neoantigen for cancer immunotherapy. Semin. Oncol. 2018, 45, 41-51. [CrossRef]

55. Ladenstein, R.; Pötschger, U.; Valteau-Couanet, D.; Luksch, R.; Castel, V.; Yaniv, I.; Laureys, G.; Brock, P.; Michon, J.M.; Owens, C.; et al. Interleukin 2 with anti-GD2 antibody ch14.18/CHO (dinutuximab beta) in patients with high-risk neuroblastoma (HR-NBL1/SIOPEN): A multicentre, randomised, phase 3 trial. Lancet Oncol. 2018, 19, 1617-1629. [CrossRef]

56. Cavdarli, S.; Dewald, J.H.; Yamakawa, N.; Guérardel, Y.; Terme, M.; Le Doussal, J.-M.; Delannoy, P.; Groux-Degroote, S. Identification of 9-O-acetyl-N-acetylneuraminic acid (Neu5,9Ac2) as main O-acetylated sialic acid species of GD2 in breast cancer cells. Glycoconj. J. 2019, 36, 79-90. [CrossRef] [PubMed]

57. Posey, A.D., Jr.; Schwab, R.D.; Boesteanu, A.C.; Steentoft, C.; Mandel, U.; Engels, B.; Stone, J.D.; Madsen, T.D.; Schreiber, K.; Haines, K.M.; et al. Engineered CAR T Cells Targeting the Cancer-Associated Tn-Glycoform of the Membrane Mucin MUC1 Control Adenocarcinoma. Immunity 2016, 44, 1444-1454. [CrossRef] 